\title{
What Will Remain? Predicting the Representation in Protected Areas of Suitable Habitat for Endangered Tropical Avifauna in Borneo under a Combined Climate- and Land-Use Change Scenario
}

\author{
Minerva Singh *D, Jessamine Badcock-Scruton and C. Matilda Collins $\mathbb{D}$ \\ The Centre for Environmental Policy, Imperial College London, London SW7 1NE, UK; \\ jbadcock-scruton@hotmail.com (J.B.-S.); t.collins@imperial.ac.uk (C.M.C.) \\ * Correspondence: ms507@ic.ac.uk
}

check for

updates

Citation: Singh, M.;

Badcock-Scruton, J.; Collins, C.M.

What Will Remain? Predicting the

Representation in Protected Areas of

Suitable Habitat for Endangered

Tropical Avifauna in Borneo under a Combined Climate- and Land-Use

Change Scenario. Sustainability 2021,

13, 2792. https://doi.org/10.3390/

su13052792

Academic Editor: Alejandro Rescia

Received: 5 February 2021

Accepted: 24 February 2021

Published: 5 March 2021

Publisher's Note: MDPI stays neutral with regard to jurisdictional claims in published maps and institutional affiliations.

Copyright: (c) 2021 by the authors. Licensee MDPI, Basel, Switzerland. This article is an open access article distributed under the terms and conditions of the Creative Commons Attribution (CC BY) license (https:/ / creativecommons.org/licenses/by/ $4.0 /)$.

\begin{abstract}
The responses of threatened tropical avian species to projected climate change and land-use change are important for evaluating the ability of the existing protected areas to provide habitat to these species under future scenarios in biodiversity hotspots. This study uses Maxent, a species distribution model that employs a maximum entropy machine learning approach to map the spatial distributions of habitats suitable for the International Union for Conservation of Nature threatened birds under present and future climate and land-use change in Borneo. We find that the existing protected areas provide very low coverage of the threatened bird species' suitable habitat areas (95\%CI $=9.3-15.4 \%$ ). Analysis of habitat suitability projections for 18 species of threatened birds suggests that in 2050, under Special Report on Emissions Scenarios A1B and B1, avian species with currently little suitable habitat may gain area but lose in the proportion of this that is protected. Large-ranged species are likely to lose habitat area and this will inflate the proportion of this remaining in protected areas. The present availability of suitable habitat was the most important determinant of future habitat availability under both the scenarios. Threat level, as measured by the International Union for Conservation of Nature and the habitat preferences considered here, Lowland or Lowland-Montane, are poor predictors of the amount of habitat contraction or expansion undergone by the species.
\end{abstract}

Keywords: biodiversity; climate change; conservation of nature; Maxent; entropy machine learning

\section{Introduction}

Climate change and anthropogenic forest loss are the greatest threats facing tropical biodiversity [1]. Many biodiversity hotspots, such as the Indo-Malayan region, which is home to many threatened and endemic species, are vulnerable to both these drivers of biodiversity decline [2,3]. The island of Borneo in the heart of this region that has seen high levels of deforestation, from $76 \%$ forest-cover $\left(560,000 \mathrm{~km}^{2}\right)$ in 1973 to approximately $53 \%$ in $2010[4,5]$. The land-use changes driving forest loss, such as agricultural expansion and poorly-regulated timber extraction, will increasingly interact with climate change, and these interactions are likely to combine to have a substantial negative impact on tropical biodiversity [6]. In the face of rapid landcover and climate changes, it is vital to evaluate the impact of these on biodiversity, including the persistence of biodiversity of tropical regions such as Borneo under future scenarios.

Birds are frequently used as umbrella species and bioindicators in conservation efforts; they are wide-spread and, unusually for tropical taxa, have relatively well-studied ecologies and life-histories [7]. Climate change and land cover change dynamics act synergistically to have a negative impact on avian persistence. Ignoring the interaction between these can undermine the robust identification of future suitable habitats [8]. They are also highly sensitive to changes in their environment, making them excellent bellwethers for global 
change research [8-10] Quantifying the potential impacts of predicted climate and landuse change scenarios on the "suitable habitat" size of threatened montane and lowland avian species will help us to predict patterns of future vulnerability at species-scale. Birds classified by the International Union for the Conservation of Nature (IUCN) as "threatened" are already vulnerable as they face considerable risk of extinction. Estimating the response of these species to potential future scenarios will be important in predicting whether these species are set to undergo further range size declines as a result of climate or landuse change and thus may require additional conservation efforts. Other studies have investigated the response of avian assemblages to these drivers in both temperate [11] and boreal zones [12,13], but Borneo, with its particular vulnerabilities, remains unexplored in this way. Further, a meta-analysis of the literature discovered future biodiversity related projections mostly consider the impact of climate change and leave out land cover. Given Borneo's rapid land cover change, it is vital to quantify the impact of both climate and landcover change on habitat suitability [14]. In addition to predicting the changes in suitable habitat available to threatened avian species, understanding this in the context of the island's protected area (PA) network under present and future scenarios will be important for informing conservation strategy both locally and across the Asian tropics.

Protected Areas are the cornerstone of conservation actions designed to ensure the long-term viability of biodiversity [15]. Tropical biodiversity-rich regions are, however, often at risk of failing to enforce the requirements of PAs, with their effectiveness limited by rapid population growth and development and additionally challenged by the triumvirate of weak institutional capacity, poverty, and corruption [16]. Threatened species do not exist exclusively within PAs, and many only find a proportion of their range protected in this way. Gap analyses can be used to quantify representation, the proportion of a species range, or of their potentially suitable habitat that lies within PAs. Biodiversity representation within the Indo-Burma hotspot PA network is already limited [17], and climate change-driven range shifts may cause the suitable habitats of vulnerable species to shift outside these [18].

The main aim of this research is to model the suitable habitat availability for the IUCN-listed threatened Bornean avian species in the island's PA network under present and future climate and land cover scenarios. To this end, the main objectives of the research are to: (a) estimate whether the suitable habitat area of these species is likely to change substantially under specific scenarios; (b) identify whether habitat availability is differentially affected by characteristics such as their habitat preference or their IUCN threat level; and, (c) evaluate the "representation" of each species" suitable habitat lying within the protected area network with the view of assessing the effectiveness of Borneo's PAs for threatened bird species, both currently and under future scenarios. This is expected to provide measure of the conservation value of IUCN PA categories (Ia-VI), to assist in identifying which protected area category is most widely valuable in terms of representation of predicted suitable habitat for the different species and identify the species at the greatest risk of losing habitats.

\section{Materials and Methods}

\subsection{Study Site}

The equatorial island of Borneo in Southeast Asia spans approximately $4^{\circ} \mathrm{S}$ to $7^{\circ} \mathrm{N}$ and $108^{\circ}$ to $118^{\circ} \mathrm{E}$. At $743,330 \mathrm{~km}^{2}$, it is Asia's largest, and the world's third-largest, island. This study focusses on the IUCN listed threatened avian species of Borneo's lowland and montane forests (see Figure 1). Avian species of both lowland and montane rainforests are vulnerable to anthropogenic disturbances [19]. 


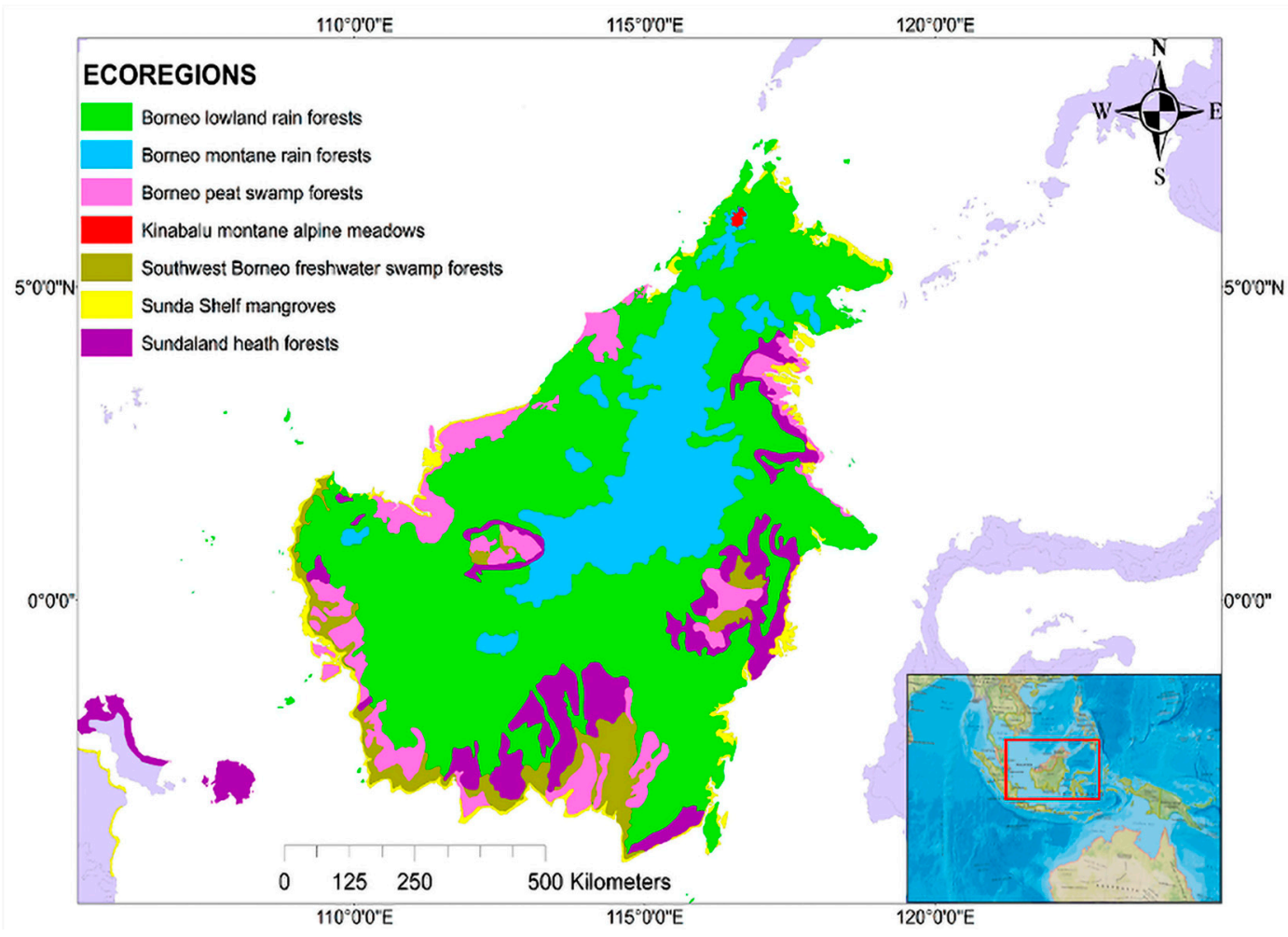

Figure 1. The seven terrestrial ecoregions of Borneo (as defined by the World-Wide Fund for Nature (WWF) with data from Dinerstein et al. [19].

\subsection{Focal Species Selection}

Bird species were selected from the IUCN Red List (IUCN, 2019), which identifies threatened species through many criteria that include population size, size of geographic range, and rate of decline. Borneo-resident species were identified then filtered to retain those occurring in Subtropical/Tropical Moist Lowland and Subtropical/Tropical Moist Montane Forests [20]. The search results were then further filtered to retain those classified as Critically Endangered, Endangered, or Vulnerable.

Point locality data for the species records were extracted from the Global Biodiversity Information Facility (GBIF) portal (GBIF.org, 2019) and filtered to a dataset of 20 species with 4766 geolocation records (Table 1). Habitat preference data, including details such as the elevational range limits of the species, were assembled from both the Handbook of the Birds of the World and the IUCN RedList species records [21]. The WWF delimits montane forests starting at around $1000 \mathrm{~m}$ above sea level [22]. Species with an upper range limit above $1000 \mathrm{~m}$ were classified as "lowland/montane", those with an upper range limit below $1000 \mathrm{~m}$ were classified as being "lowland" residents (Table 1).

\subsection{Environmental Data}

\subsubsection{Present Climate Data}

Environmental data, consisting of 19 bioclimatic variables at a spatial resolution of 30 arc seconds (approximately $1 \mathrm{~km}$ at the equator) and representing aggregated climate data from 1970 to 2000, were downloaded in raster format from WorldClim 2.0 [23]. These variables are obtained through a thin-plate spline smoothing algorithm that interpolates data from a large number of weather stations across the globe. The 19 variables represent climate factors of varying temporal scales, from annual and seasonal trends to extreme monthly and quarterly variables that may prove to be limiting factors to flora and fauna [24]. After a preliminary model assessment, nine of the 19 WorldClim variables were retained (Table 2); the ten variables which consistently contributed little or nothing to the model 
explanatory power were excluded. The elimination of these redundant variables also reduced multicollinearity between variables and potential model overfitting [21].

Table 1. The bird species included in this dataset along with their International Union for the Conservation of Nature (IUCN) classification and habitat preferences.

\begin{tabular}{|c|c|c|c|}
\hline Species (Latin) & Species (Common) & IUCN Category & Habitat Preference \\
\hline Aceros corrugatus & WrinkledHornbill & EN & $\begin{array}{l}\text { Lowland evergreen forest extends into the selectively logged } \\
\text { forest (Kemp, A.C, Boesman, P and Sharpe, 2019) }\end{array}$ \\
\hline Anthracoceros malayanus & Black hornbill & VU & $\begin{array}{c}\text { Lowland primary forest, mostly <200 m, very occasionally up } \\
\text { to } 600 \mathrm{~m}(\text { Kemp, Boesman and Sharpe, 2019) }\end{array}$ \\
\hline Berenicornis comatus & White-crowned hornbill & EN & $\begin{array}{l}\text { Primary lowland and sometimes montane forest up to } 1675 \mathrm{~m} \\
\text { (A. C. Kemp and Boesman, 2019b) }\end{array}$ \\
\hline Buceros rhinoceros & Rhinoceros hornbill & VU & $\begin{array}{l}\text { Primary lowland forest, extending into the secondary forest up } \\
\text { to } 1400 \mathrm{~m} \text { (A. C. Kemp and Boesman, 2019a) }\end{array}$ \\
\hline Caprimulgus concretus & Bonaparte's Nightjar & VU & $\begin{array}{l}\text { Lowland dipterocarp forest and secondary growth, sea level to } \\
\qquad 500 \mathrm{~m} \text { (Cleere and Sharpe, 2019) }\end{array}$ \\
\hline Centropus rectunguis & Centropus rectunguis & VU & The undergrowth of lowland forest (Payne and de Juana, 2019) \\
\hline Chloropsis sonnerati & Greater green leafbird & VU & $\begin{array}{l}\text { Lowland evergreen forest, extending up to } 1100 \mathrm{~m} \text { (Wells and } \\
\text { Sharpe, 2019) }\end{array}$ \\
\hline Ciconia stormi & Storm's stork & EN & Undisturbed lowland forest \\
\hline Cyornis caerulatus & Sunda Blue Flycatcher & VU & Lowland dipterocarp forest, sea-level to $<500 \mathrm{~m}$ (Clement, 2019) \\
\hline Hydrornis baudii & blue-headed pitta & VU & Lowland primary forest extends up to $600 \mathrm{~m}$ (Erritzoe, 2019) \\
\hline Leptoptilos javanicus & Lesser adjutant & VU & Mangroves, coastland wetlands adjacent to lowland forest \\
\hline Mulleripicus pulverulentus & Great slaty woodpecker & VU & $\begin{array}{l}\text { Semi-open tropical lowland forests, extending up to } 2000 \mathrm{~m} \\
\text { (Winkler, Christie and Kirwan, 2019) }\end{array}$ \\
\hline Nisaetus nanus & Wallace's hawk-eagle & VU & Lowland forest, rarely up to $1000 \mathrm{~m}$ (Clark and Kirwan, 2019) \\
\hline Psittacula longicauda & Long-tailed parakeet & VU & Extreme lowland, $<300 \mathrm{~m}$ (Collar and Sharpe, 2019) \\
\hline Ptilocichla leucogrammica & Bornean wren-babbler & VU & $\begin{array}{l}\text { Lowland dipterocarp forest extends into the montane forest } \\
\text { (Collar and Robson, 2019) }\end{array}$ \\
\hline Rhinoplax vigil & Helmeted hornbill & $\mathrm{CR}$ & Extends up to 1500 m (Kemp, Sharpe and Boesman, 2019) \\
\hline Rhyticeros undulatus & Wreathed hornbill & VU & $\begin{array}{l}\text { Occasionally lowland forest extends up to } 2560 \mathrm{~m} \text { (A. Kemp } \\
\text { and Boesman, 2019) }\end{array}$ \\
\hline Setornis criniger & hook-billed bulbul & VU & Lowland forest, extending up to 1000 m (Myers, 2016b) \\
\hline Spilornis kinabaluensis & Mountain serpent eagle & VU & $\begin{array}{l}\text { Montane and sub-montane forests, preferably ridgetops, } \\
\text { 750-2900 m (Clark, Kirwan and Christie, 2019) }\end{array}$ \\
\hline Treron capellei & large green pigeon & VU & Lowland forest, preferably primary forest (Baptista et al., 2019) \\
\hline
\end{tabular}

Table 2. The area of suitable habitat available to each bird species under the modelled current (2010) scenario and the percent of this suitable habitat that currently lies within a protected area (PA).

\begin{tabular}{|c|c|c|c|c|c|}
\hline $\begin{array}{c}\text { Available Range } \\
\text { Size }\end{array}$ & IUCN Status & Species & Habitat Type & $\begin{array}{c}\text { Suitable Available } \\
\text { Habitat }\left(\mathrm{km}^{2}\right)\end{array}$ & $\begin{array}{c}\text { Habitat within } \\
\text { a PA (\%) }\end{array}$ \\
\hline \multirow{4}{*}{ Large } & VU & Buceros rhinoceros & Lowland/Montane & 36,400 & 11.1 \\
\hline & VU & Ptilocichla leucogrammica & Lowland/Montane & 44,616 & 6.16 \\
\hline & CR & Rhinoplax vigil & Lowland & 50,166 & 5.9 \\
\hline & VU & Rhyticeros undulatus & Lowland/Montane & 41,200 & 18.2 \\
\hline \multirow{9}{*}{ Medium } & VU & Anthracoceros malayanus & Lowland & 25,554 & 9.6 \\
\hline & $\mathrm{EN}$ & Berenicornis comatus & Lowland/Montane & 12,721 & 13.4 \\
\hline & VU & Caprimulgus concretus & Lowland & 10,431 & 20.5 \\
\hline & VU & Centropus rectunguis & Lowland & 15,404 & 14.2 \\
\hline & VU & Cyornis caerulatus & Lowland & 21,760 & 15.5 \\
\hline & VU & Hydrornis baudii & Lowland & 25,542 & 14.9 \\
\hline & VU & Mulleripicus pulverulentus & Lowland/Montane & 22,292 & 8.6 \\
\hline & VU & Psittacula longicauda & Lowland & 21,394 & 6.7 \\
\hline & VU & Treron capellei & Lowland & 15,702 & 3.4 \\
\hline \multirow{5}{*}{ Small } & VU & Aceros corrugatus & Lowland & 8844 & 8.2 \\
\hline & $\mathrm{EN}$ & Ciconia stormi & Lowland & 3950 & 11.5 \\
\hline & VU & Leptoptilos javanicus & Lowland & 5957 & 6.5 \\
\hline & VU & Nisaetus nanus & Lowland & 9639 & 16.4 \\
\hline & VU & Spilornis kinabaluensis & Lowland/Montane & 7881 & 30.2 \\
\hline
\end{tabular}

\subsubsection{Future Climate Data}

Tiles of spatially downscaled climate model data for all 19 bioclimatic variables were downloaded from the CCAFS-Climate data portal (http: / / www.ccafs-climate.org (1 March 
2021)) at the same resolution. Future climate change scenarios for the time interval 20462065 (mean $=2050$ ) were considered. Future climate projections were derived from CSIRO Mk3.5, a General Circulation Model (GCM) used in the Coupled Model Intercomparison Project 3 (CMIP3). Simulations from the Mk3 family of models have contributed towards the IPCC AR4 Assessment and have been used in modelling bat and bird distributions in Southeast Asia and South America [22,25]. For this period, the climate parameters of two IPCC Special Report on Emissions Scenarios (SRES), A1B, and B1, both representing medium-high and lower emissions scenarios, respectively, were used. Thus, two future climate scenarios were modelled and considered in this study: A1B 2050 and B1 2050.

\subsubsection{Topographic Data}

Digital elevation data from the Shuttle Radar Topography Mission (STRM) was downloaded in $5 \times 5^{\circ}$ tiles from the CGIAR Consortium for Spatial Information at a resolution of $90 \mathrm{~m}$. It was assumed that topographic data would remain stable in this time frame. An additional topographic variable raster, slope, was also generated from the SRTM elevation raster.

\subsubsection{Land-Use Data}

A Future Land-Use Simulation (FLUS) system modelling land-use and land cover change at a fine resolution of $1 \mathrm{~km}$ was downloaded for the years 2010, A1B, and B1 2050 from [26]. As with the climate change scenarios, the land-use scenarios arrived-at reflect predicted demographic, economic, climate change, and energy requirement drivers for the years stated, with the land-cover scenarios derived using a combination of "top-down" agro-economic allocation and "bottom-up" spatial modelling [26].

\subsubsection{Layer Preparation}

The modelling of suitable habitat for all 20 species across all periods and SRES scenarios is implemented with the Maxent model of 12 variables (Table S1: The twelve (12) bioclimatic, topographic and land-use variables used as input variables in the MaxEnt modelling).

\subsubsection{Protected Area Data}

The Bornean PA network shapefile data was supplied by the World Database on Protected Areas (WDPA), ProtectedPlanet.net. The WDPA provided a comprehensive and global database of terrestrial and marine protected areas and was set up by the UN Environment Programme and the IUCN [27]. The IUCN categories PAs according to several guidelines and management approaches [28]. Strictly protected areas, in which it is recommended that extractive and mining activities are prohibited, constitute categories I-IV, while categories V-VI permit localized extractive activities [28]. Only categories Ia-VI from the downloaded dataset were considered; any PA listed as "Not Reported" or "Not Applicable" by the IUCN was excluded. A total of 213 protected areas were included in the analysis (Figure 2).

\subsubsection{Habitat Suitability Modelling}

For each species, one current (2010) distribution and two SRES scenario future distributions were modelled (total $=60$ ) using the maximum entropy modelling software Maxent [29]. The default settings were used; the regularization parameter (used to reduce overfitting) was fixed at 1 , and the maximum number of background points was set at $10,000[28,30]$. The replicated run type was set to "cross-validate", and the number of iterations to 500. These auto-features have been previously validated and tuned [31,32]. Estimates of the independent contribution of each variable to the model outcome were calculated. However, these are heuristically defined and path-dependent. Jackknife tests were additionally used to estimate the importance of each variable [33]. 


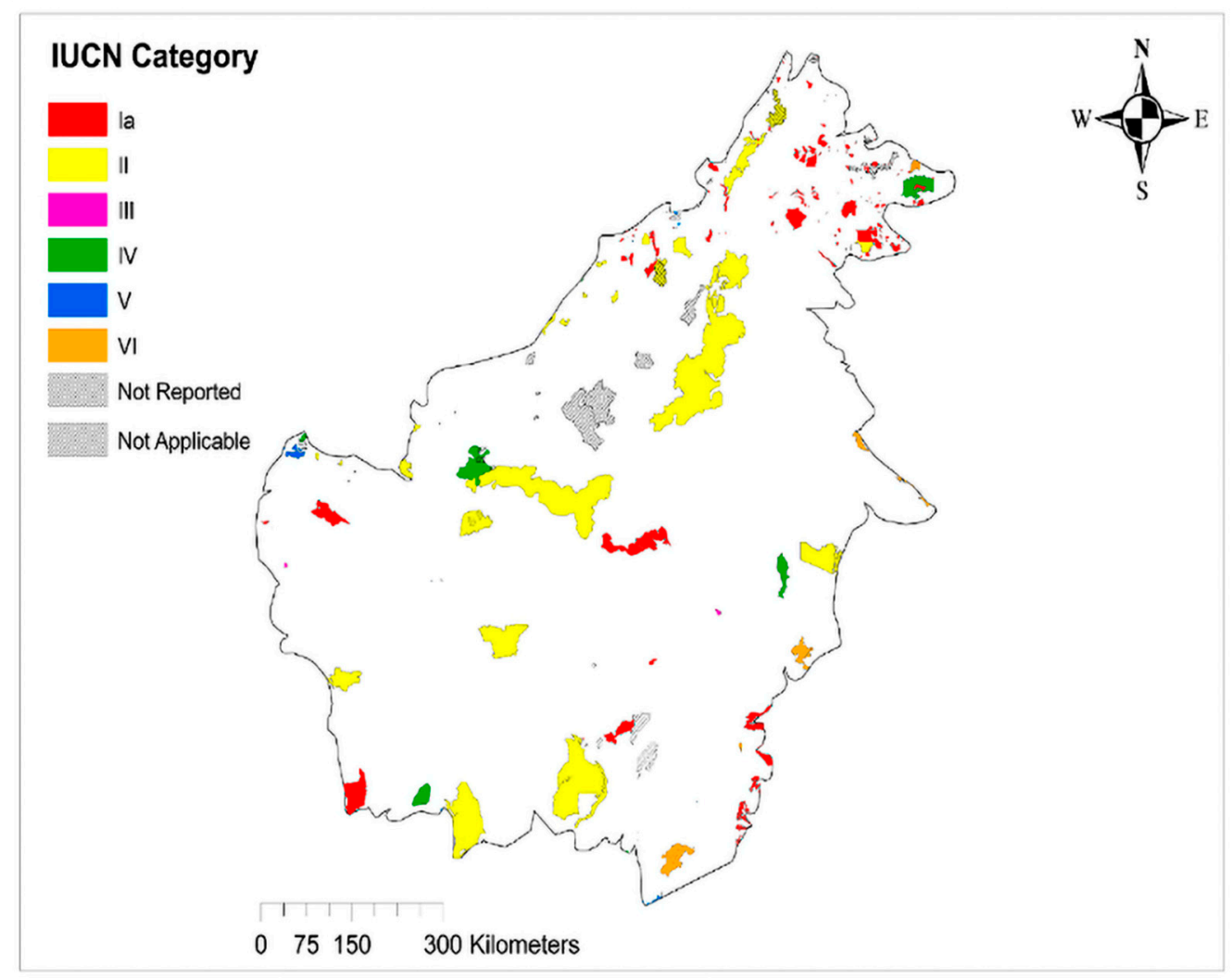

Figure 2. Protected Area Network Protected areas of Borneo, classified according to their IUCN category. Mapped in ArcMap using data taken from UNEP-WCMC (UN Environment Programme World Conservation Monitoring Centre) and Protected Planet (2019).

In the absence of independent data for model validation, the dataset was randomly partitioned into test $(25 \%)$ and training $(75 \%)$ data (as used in $[27,29,34]$ ). Model quality was assessed using the area under the receiver operating characteristic (ROC) curve (AUC), a threshold-independent metric and true skill statistics (TSS) [34]. The ROC value is obtained by plotting sensitivity (proportion of known presence predicted present $(=1$-false negative rate)) against 1-specificity (proportion of known absences predicted present (=false positive rate)) [35]. The resulting test area under the curve (AUC) value ranges from 0 to 1 , with 1 indicating a model with perfect discrimination and an AUC of 0.5 , indicating that model performance is equivalent to that of random prediction [36]. TSS scores are classified as moderate performance $(\geq 0.5)$, fair performance $(\geq 0.3)$, and poor performance $(<0.3)$ [37]. Two species with test AUC values $<0.75$ (Chloropsis sonnerati, Setornis criniger) were then excluded as this threshold indicates reasonable discriminatory power [27,32]. All the remaining species had a TSS $>0.6$.

The Maxent logistic output format produces continuously scaled distribution maps of habitat suitability on a scale from 0 to 1 , where cells assigned a value of 1 to contain theoretically high habitat suitability, and cells with a value of 0 are considered highly unsuitable. These maps were converted into binary presence/absence maps by setting a probability of occurrence threshold of 0.6 , as recommended by Nazeri et al. [38]. This conservative approach is often preferred in conservation contexts, where a more liberal interpretation of a probability of habitat suitability could result in the misdirection of resources [39].

\subsubsection{Habitat Suitability and Protected Area Coverage Calculation and Analysis}

Binary maps were used to calculate the absolute area of the habitat suitability for each of the species in 2010 and in 2050 under the two future scenarios modelled (A1B/B1). The suitable habitat available was classified into three levels, Small $\left(<10,000 \mathrm{~km}^{2}\right)$, Medium 
$\left(10,000-30,000 \mathrm{~km}^{2}\right)$ and Large $\left(>30,000 \mathrm{~km}^{2}\right)$. The overlap of the habitat suitability maps and the protected areas was calculated using Zonal Statistics [40].

We used an analysis of covariance (ANCOVA) to investigate whether the current IUCN categorization, the 2010 suitable habitat area, and the habitat type preference varied systematically with predicted changes in habitat area and in the portion of suitable habitat predicted to lie within protected areas in 2050. The ICUN categories CR and EN were collapsed to a single level, "EN+", in the analysis as there was a single species in the CR category. Generalized linear models were fit independently to the species predictions arising from modelling of the two future scenarios and the influence of each factor/variable was assessed by sequential deletion testing until the minimally adequate model was identified. Only main effects and no interactions were fit as the data set was small. All analyses were performed in $\mathrm{R}$ version 3.6.3 [41].

\section{Results}

All the current and future habitat suitability maps retained in this analysis performed well, with mean testing and training AUC values of $0.892( \pm 0.051)$ and $0.936( \pm 0.036)$, respectively. Isothermality (Bio3) was the most important predictor of species distribution for the present time period and was the highest contributing variable in $52.6 \%$ of cases with an average explanatory contribution of $41 \%$. In all four future scenarios, precipitation of the driest quarter (bio17) was the most important predictor, ranking as the highest contributor in the model $31.7 \%$ of the time and contributing, on average, $32.9 \%$. A jackknife test of variable importance confirmed bio17 to be the highest contributing variable of $32.3 \%$ of the time.

One species, Caprimulgus concretus, was predicted to make such habitat gains $(>200 \%)$ that it was an outlier in both future models and was excluded from the statistical analyses of habitat area change as it obscured the generality of interpretation. Modelling was, however, performed with, and without, this species to confirm general patterns. These did not vary, but model fit was much improved with the outlier removed.

\subsection{Current (2010) Habitat Suitability Modelling and Estimated Portion Protected}

The available habitat predicted to be suitable for each species varied substantially. Buceros rhinoceros, a large-bodied hornbill has over $50,000 \mathrm{~km}^{2}$ available whereas Ciconia stormi, the rarest of all storks, has less than $3000 \mathrm{~km}^{2}$ of suitable undisturbed forest remaining on Borneo. The percentage of the available habitat lying within protected areas was low $(95 \% \mathrm{CI}=9.3-15.4 \%)$ but also varied substantially from Spilornis kinabaluensis, the Mountain Serpent Eagle, which prefers high ridges and has $>30 \%$ within PAs to Treron capellei, a large, green pigeon, with only $3.4 \%$ of its range protected (Table 2$)$. The largeranged, critically-endangered Rhinoplax vigil had only $5.9 \%$ of its suitable habitat within the protected areas.

\subsection{Future Habitat Suitability Modelling and Estimated Portion Protected}

The details of predictions for each species varied slightly between the two modelled scenarios, but their general behavior was largely similar (Table 3). All species with current large areas of habitat available are predicted to lose under both future climate scenarios. The picture is more mixed in the species with less habitat currently available to them. In the medium category $\left(10,000-30,000 \mathrm{~km}^{2}\right)$, five of the nine are predicted to have more habitat available in future with Caprimulgus concretus, Bonaparte's nightjar, being predicted to gain substantially (Table 3). In the species with small areas of suitable habitat currently available, only one, Spilornis kinabaluensis, the Mountain Serpent Eagle, was predicted by both models to lose over a fifth of its currently suitable area; the others are predicted to make habitat gain. 
Table 3. Predicted changes (\%) in suitable habitat availability on the island of Borneo and the change in portion (\%) of a species' range that lies within a protected area between 2010 and 2050. Two future scenarios were modelled independently, A1-B (Medium-high emissions) and B1 (Low emissions).

\begin{tabular}{|c|c|c|c|c|c|c|}
\hline \multirow[t]{2}{*}{$\begin{array}{l}\text { Available } \\
\text { Range Size }\end{array}$} & \multirow[t]{2}{*}{$\begin{array}{l}\text { IUCN } \\
\text { Status }\end{array}$} & \multirow[t]{2}{*}{ Species } & \multicolumn{2}{|c|}{$\begin{array}{l}\text { Predicted Change in Range Size over } \\
\text { the } 2010-2050 \text { Window (\%) }\end{array}$} & \multicolumn{2}{|c|}{$\begin{array}{l}\text { Predicted Change in the Portion of } \\
\text { the Range Found within a PA over } \\
\text { the 2010-2050 Window (\%) }\end{array}$} \\
\hline & & & Scenario A1-B & Scenario B1 & Scenario A1-B & Scenario B1 \\
\hline \multirow{4}{*}{ Large } & VU & Buceros rhinoceros & -10.41 & -7.10 & 0.67 & -2.53 \\
\hline & VU & Ptilocichla leucogrammica & -71.22 & -66.20 & 6.16 & 4.14 \\
\hline & CR & Rhinoplax vigil & -32.15 & -37.45 & 2.01 & 0.79 \\
\hline & VU & Rhyticeros undulatus & -12.12 & -3.91 & 1.10 & -2.82 \\
\hline \multirow{9}{*}{ Medium } & VU & Anthracoceros malayanus & 19.21 & 37.74 & -3.59 & -4.11 \\
\hline & $\mathrm{EN}$ & Berenicornis comatus & 22.26 & 51.09 & -3.80 & -6.50 \\
\hline & VU & Caprimulgus concretus & 292.22 & 207.51 & -11.90 & -13.86 \\
\hline & VU & Centropus rectunguis & 13.49 & 26.09 & -7.44 & -8.44 \\
\hline & VU & Cyornis caerulatus & -5.58 & -25.75 & -0.27 & 0.88 \\
\hline & VU & Hydrornis baudii & -31.47 & -30.46 & 2.39 & 1.09 \\
\hline & VU & Mulleripicus pulverulentus & -6.57 & 2.08 & -2.96 & -4.41 \\
\hline & VU & Psittacula longicauda & 9.32 & 27.34 & -2.97 & -3.88 \\
\hline & VU & Treron capellei & -16.57 & -2.01 & 1.90 & 0.93 \\
\hline \multirow{5}{*}{ Small } & VU & Aceros corrugatus & 67.31 & 39.15 & -2.52 & -3.99 \\
\hline & $\mathrm{EN}$ & Ciconia stormi & 16.63 & 19.18 & -4.64 & -5.14 \\
\hline & VU & Leptoptilos javanicus & 19.25 & 21.67 & -2.38 & -3.63 \\
\hline & VU & Nisaetus nanus & 79.49 & 84.81 & -10.12 & -10.65 \\
\hline & VU & Spilornis kinabaluensis & -20.94 & -24.49 & -6.73 & -5.01 \\
\hline
\end{tabular}

Protected area coverage (\%) of suitable habitat is projected to decline for all bird species with small available ranges by 2050. For the four species with more than $30,000 \mathrm{~km}^{2}$ available currently, the percent coverage is mostly projected to increase, though this is largely an artefact of substantial range loss outside PAs (Table 3).

Although the details of predictions for each species varied slightly between the two modelled emissions scenarios, their general behavior was largely similar (Table 3). Although each scenario was analyzed independently, the statistical summaries reflect this similarity and are largely concordant, though the effects of the higher emissions scenario A1-B are more marked (Table 4).

Table 4. Statistical summary of the deletion tests of the variables assessed as potentially associated with the change in range size, and the percentage of range protected for eighteen Bornean bird species between 2010 and 2050. The calculated F-ratio (F), the degrees of freedom (d.f.) associated with the comparison and its probability (p) are presented.

\begin{tabular}{|c|c|c|c|c|c|c|c|c|}
\hline & \multicolumn{4}{|c|}{$\begin{array}{l}\text { Scenario B1 Predictions } \\
\text { (Low Emissions) }\end{array}$} & \multicolumn{4}{|c|}{$\begin{array}{l}\text { Scenario A1B Predictions } \\
\text { (Medium-High Emissions) }\end{array}$} \\
\hline \multicolumn{9}{|c|}{ Predicted Change in Suitable Habitat between 2010 and 2050} \\
\hline & $\mathrm{F}$ & d.f. & $\mathrm{p}$ & effect & $\mathrm{F}$ & d.f. & $\mathrm{p}$ & Effect \\
\hline IUCN Category & 0.09 & 1,13 & 0.77 & none detected & 0.00 & 1,13 & 0.97 & none detected \\
\hline Habitat & 0.28 & 1,14 & 0.60 & none detected & 1.10 & 1,14 & 0.31 & none detected \\
\hline Current (2010) area available & 9.35 & 1,15 & 0.008 & $\begin{array}{l}\text { Greater loss for large } \\
\text { ranged-species }\end{array}$ & 11.24 & 1,15 & 0.004 & $\begin{array}{l}\text { Greater loss for large } \\
\text { ranged- species }\end{array}$ \\
\hline \multicolumn{9}{|c|}{ Predicted change in the proportion of the suitable habitat within a currently protected area between 2010 and 2050} \\
\hline & $\mathrm{F}$ & d.f. & $\mathrm{p}$ & effect & $\mathrm{F}$ & d.f. & $\mathrm{p}$ & Effect \\
\hline IUCN Category & 0.08 & 1,13 & 0.78 & None detected & 0.08 & 1,13 & 0.77 & None detected \\
\hline Habitat & 0.11 & 1,14 & 0.77 & None detected & 1.04 & 1,14 & 0.33 & None detected \\
\hline Current (2010) coverage in PAs & 2.45 & 1,15 & 0.14 & None detected & 4.39 & 1,15 & 0.05 & None detected \\
\hline Current (2010) area available & 8.93 & 1,16 & 0.008 & $\begin{array}{l}\text { Most loss at higher } \\
\text { initial coverage }\end{array}$ & 13.24 & 1,16 & 0.002 & $\begin{array}{l}\text { Most loss at higher } \\
\text { initial coverage }\end{array}$ \\
\hline
\end{tabular}

The predicted change in range was not detected to vary between the IUCN categories nor with whether the species preferred a Lowland or Lowland/Montane habitat. The suitable habitat available in 2010 was an effective predictor and greater habitat loss was observed in larger ranges. The portion of the range that lay within a protected area had 
a similar pattern with systematic variation identified with the area of habitat available in 2010. For this the pattern was a greater loss of habitat protection in small-ranged species than in large-ranged ones (Figure 3a). The portion of range within PAs in 2010 displays a clear visual pattern, but its importance is not statistically convincing in this small data set and may be obscured by the influence of the 2010 area available (Figure $3 \mathrm{~b}$ and Table 4). This tentatively suggests that species with higher 2010 levels of habitat coverage within protected areas were also predicted to lose most protection under future scenarios.
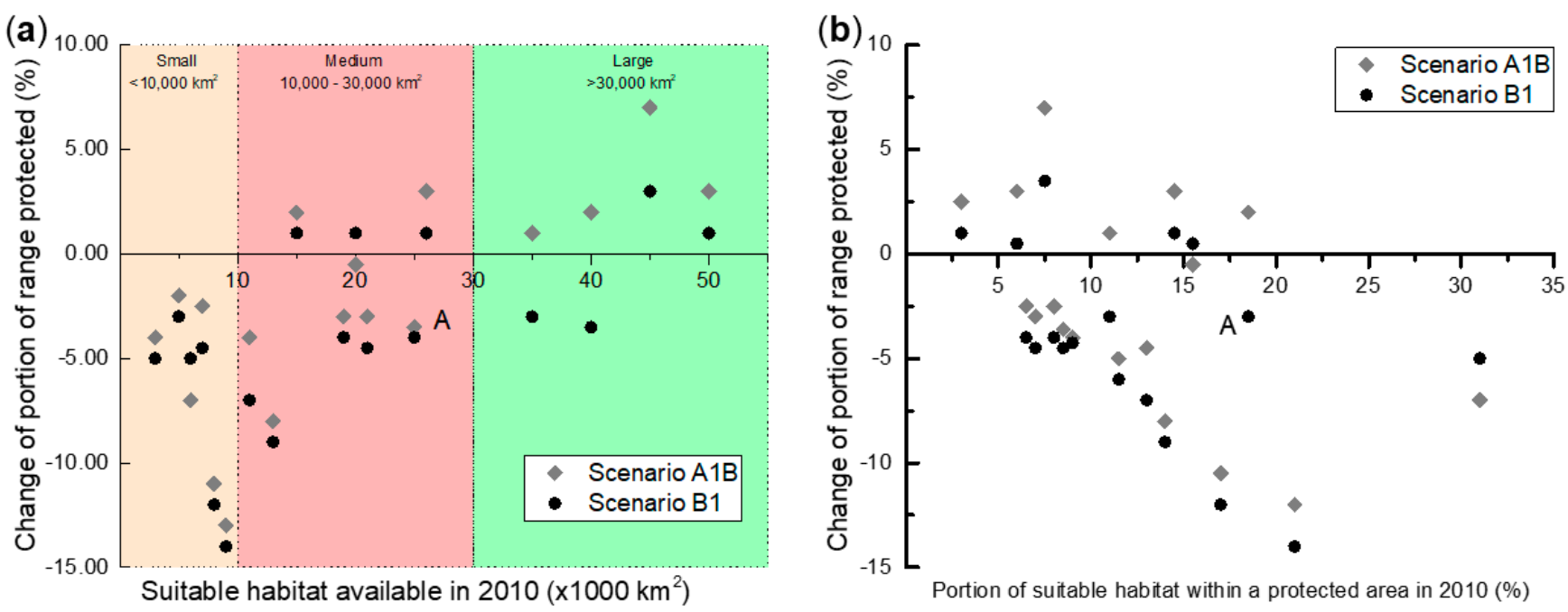

Figure 3. Change in percentage of suitable habitat lying within a Protected Area (PA) by (a) estimated area of suitable habitat in 2010 and (b) The portion of this that lay within a PA in 2010. Two future scenarios were modelled independently: A1-B (Medium-high emissions) and B1 (Low emissions).

\section{Discussion}

\subsection{Changes in the Area of Suitable Habitat}

In our research we have used a combination of climate change and land cover variables to predict the changes in bird habitat suitability under different future scenarios. Incorporating land cover change dynamics is important for generating robust habitat suitability forecasts. Ignoring the interaction between these can undermine the robust identification of future suitable habitats [8]. Previous research indicates that land-use change is likely to interact with climate change and that these climates-land-use change interactions are likely to have a significant impact on tropical biodiversity [6]. Climate change and vegetation changes are expected to act in conjunction to cause a decline in the species richness of bats of SE Asia circa 2050-2080 under a high emissions scenario [6]. Previous SE Asia wide research has indicated that future forest loss will decrease suitable habitats for threatened birds within PAs [42]. While incorporating landcover change dynamics is important for habitat suitability modelling, the uncertainties in land cover interpretation need to be accounted for [43]. In case of Borneo, it is important to develop regional scale future land cover scenarios such as these [44] which also account for the spread of infrastructure [45] and oil palm plantations.

Both climate and land cover change have been seen to, and, are expected to have future impact on tropical bird biodiversity and the interaction between these factors is projected to increase the impact on bird species by altering the spatial distribution of threats [46]. Looking beyond the frame of our work, projected climate change for the period 2061-2080 is expected to severely inhibit the ability of Borneo's protected areas to conserve avian species and biodiversity in general; these are expected to have different climatic conditions relative to today [42,47]. Our research examined a subset of Borneo's threatened avian species and identified "winners" and "losers" under different future scenarios. Further, 
we identified some of the attributes that potentially make different avian species more vulnerable to losing suitable habitat.

By showing that restricted-range birds are estimated to lose the greatest proportion of suitable habitat we support existing observational and experimental studies that have reported the looming threat of range contractions for smaller-ranged avian species (e.g., in Peruvian and New Guinean birds [48,49], and in a global dataset [50]. Simple temperature change-based modelling predicts that $53 \%$ of lowland species face lowland biotic attrition [51], here we did not detect a habitat association and may have been constrained by the particular avian subset used. Our findings do coincide with studies such as those by Freeman et al. [40] and Ramiles-Villegas et al. [52]; in the first, Peruvian lowland birds were seen to expand their ranges, while in the latter birds in the tropical Andes were predicted to be either unaffected or even favored by the warming climatic conditions in 2050 , with $45 \%$ of birds estimated to undergo expansions in their climate niche in the range of $100 \%$ or more. These suggest that lowland bird species can expand their range size as a consequence of the leading edges of their distribution shifting upslope as climate conditions at higher elevations become more agreeable [48]. Climate change can, therefore, result in the promotion of range expansion under some circumstances, for instance when lowland birds prefer drier/warmer conditions that could be provided under future climate change [53]. We find no discernible difference in the predicted change in size of suitable habitat between EN+ and VU categories. This agrees with previous studies of birds in finding that IUCN threat status is not only associated with range size and predictions of range size alteration under future scenarios [54].

\subsection{Representation of Threatened Avifauna in the BORNEAN PA Network}

The variation in the portion of suitable habitat represented in PAs is substantial among the species used here. Rodrigues et al. proposed a scale of "appropriate representation" relating the habitat available or potential range of a bird species to the proportion of this range that should be protected [55]. For the suitable habitat extents modelled here, these species should achieve $76.9-100 \%$ representation of suitable habitat within the PA network. The highest we identify is just over $30 \%$ in S. kinabaluensis and this is also the species predicted to fall to around a $10 \%$ representation within PAs over the window modelled. Although more than $16 \%$ of Borneo is protected, the representation afforded by the PA network suggested by this study — both now and under future scenarios-remains woefully below the levels of adequacy recommended. Although this study does not identify any species with no suitable habitat within PAs, or "gap species", all species as modelled here classify as "partial gap" species according to the definition of [55] and none are afforded adequate protection. The small-ranged avian species modelled here are highly likely to undergo a greater decline in suitable protected habitat availability and have been identified elsewhere as vulnerable to suitable habitat decline under future climate scenarios [9] and to loss of habitat for such species are rapidly affected by high levels of land cover change [54]. A similar study of range-restricted species in the Andes also suggested a habitat decline in protected areas under different future climate scenarios [25].

\subsection{Conservation Implications and Recommendations}

There are already very-low to low levels of representation of threatened birds within Bornean PAs, and with land-use change predicted to increase outside of PAs, efforts must be focused towards preserving what little is still protected. This should include efforts to monitor populations of birds in PAs that have been flagged as being potentially at higher risk of habitat decline (e.g., small-ranged and specialist birds). Protected areas do have a positive effect on maintaining the diversity of range-restricted species [56-58] and inclusion of existing nature reserves into the formal PA network system was recommended as a way of conserving the habitats of small-ranged birds [59]. Further, protected areas can mitigate the climate change impacts and are an effective tool for conservation in a changing climatic world [60]. However static reserve networks are likely to struggle to 
account for future climate change scenarios. This message, that areas under protection will have to shift or expand under climate change scenarios is likely universal. Analyses of the habitat dynamics of all vertebrate classes, including identifying refugia and habitat areas that are suitable for species both under present and future climate change scenarios has been recommended [61]. Future conservation in this region could benefit substantially by expanding the protected areas to ensure that their configuration in terms of size and connectivity account for future scenarios [62].

The climate change related variables we identify as the strongest drivers of change in suitable habitat under the future scenarios, precipitation in the driest quarter and isothermality, have been noted in other studies. A global scale analysis revealed that these aspects of climate change remain drivers of species habitat availability, and, in many tropical ecosystems, surpass the importance of land cover change [63]. Borneo, however, faces rapid forest loss with oil palm plantation cultivation driving deforestation and population expansion driving other agriculture. Future oil palm expansion is projected to have a damaging impact on ecosystems worldwide [64,65]. However, no specific Bornean projections exist of the future temporal-spatial distributions of these agricultural plantations and this makes it difficult to quantify habitat availability in the face of future climate change and oil palm expansion. The climate and land use change scenarios modelled here are thus not necessarily representative of real-life trajectories; scenario B1, for example, represents full mitigation of emissions and a decrease in farmland. In reality, we have passed the point of such complete mitigation. Given the current political and economic climate, a business-as-usual scenario predicts that we will reach much higher emissions scenarios than those used by this study. Similarly, decreasing cropland, as predicted in B1, is a scenario that is improbable, given the current population growth trajectory and land conversion rates [26]. Consequently, the effects of some of the patterns reported in this study (e.g., decrease in range size for small-ranged) would almost certainly be magnified under a more realistic scenario. In addition, the omission of certain species-specific factors such as those pertaining to physiology from our model may have resulted in an overestimate of the suitable habitat size of species under future scenarios.

\section{Conclusions}

Threatened bird species can act as an indicator group for patterns of predicted biodiversity change. Employing climatic, topographic, and land-use variables in maximum-entropy modelling, we find that overall, the threatened avian species found in the lowland and montane regions of Borneo are not predicted to experience vast range size contractions in the next century in either an A1B or a B1 world. Some assemblages, however, may be "losers" (e.g., large-ranged birds) under future scenarios, while others may be "winners" as they are predicted to expand their suitable habitat (e.g., birds with small areas of habitat currently available to them). The majority of modelled suitable habitat, both now and in the future, was found to lie outside of current PA boundaries, with no species approaching the recommended representation targets. This work reinforces conservation messages from other taxa and biogeographic regions. Suggested conservation actions include both localized (e.g., increasing the area and ensuring the persistence of individual upland PAs) and regional-scale (e.g., managing wider landscapes, for example, through retaining selectively logged forests as a complement to PAs) approaches.

Borneo, although undergoing some of the most extensive changes globally in terms of forest conversion and habitat degradation, is not unique in the situation it faces. Southeast Asia generally is not only a biodiversity hotspot, but also a hotspot of threats, and as such, the conservation recommendations we make apply widely.

Supplementary Materials: The following are available online at https:/ / www.mdpi.com/2071-105 0/13/5/2792/s1, Table S1: The twelve (12) bioclimatic, topographic and land-use variables used as input variables in the MaxEnt modelling. 
Author Contributions: M.S.: Conceptualization, Methodology, Software Support, Writing; J.B.-S.: Data Sourcing, Data Curation, Analysis, Draft Preparation; C.M.C.: Oversight, Analysis, Support and Guidance, Writing, Editing. All authors have read and agreed to the published version of the manuscript.

Funding: This research received no external funding.

Institutional Review Board Statement: Not applicable.

Informed Consent Statement: Not applicable.

Data Availability Statement: Data were obtained from various public sources: http:/ /www.ccafsclimate.org (accessed on 1 March 2020). https:/ / www.gbif.org/dataset-classes/ (accessed on 10 March 2020). https:/ / www.unep-wcmc.org/resources-and-data/ (accessed on 1 March 2021). https: / / www.iucn.org/resources / conservation-tools (accessed on 1 March 2020). https: / / www.worldclim. org; https:/ / www.worldwildlife.org/pages/conservation-science-data-and-tools (accessed on 1 March 2021).

Acknowledgments: We would like to thank Maria Vinogradova, Mark Burgman and the CEP of Imperial College London for the supportive atmosphere that they provide.

Conflicts of Interest: The authors declare no conflict of interest.

\section{References}

1. Sala, O.E.; Chapin, F.S.; Armesto, J.J.; Berlow, E.; Bloomfield, J.; Dirzo, R.; Huber-Sanwald, E.; Huenneke, L.F.; Jackson, R.B.; Kinzig, A.; et al. Global biodiversity scenarios for the year 2100. Science 2000, 287, 1770-1774. [CrossRef]

2. Myers, N.; Mittermeier, R.A.; Mittermeier, C.G.; Da Fonseca, G.A.B.; Kent, J. Biodiversity hotspots for conservation priorities. Nature 2000, 403, 853-858. [CrossRef] [PubMed]

3. Foden, W.B.; Butchart, S.H.M.; Stuart, S.N.; Vié, J.-C.; Akçakaya, H.R.; Angulo, A.; DeVantier, L.M.; Gutsche, A.; Turak, E.; Cao, L.; et al. Identifying the World's Most Climate Change Vulnerable Species: A Systematic Trait-Based Assessment of all Birds, Amphibians and Corals. PLoS ONE 2013, 8, e65427. [CrossRef]

4. Curran, L.M.; Trigg, S.N.; McDonald, A.K.; Astiani, D.; Hardiono, Y.M.; Siregar, P.; Caniago, I.; Kasischke, E. Lowland Forest Loss in Protected Areas of Indonesian Borneo. Science 2004, 303, 1000-1003. [CrossRef]

5. Hughes, A.C. Understanding the drivers of Southeast Asian biodiversity loss. Ecosphere 2017, 8, e01624. [CrossRef]

6. Brodie, J.; Post, E.; Laurance, W.F. Climate change and tropical biodiversity: A new focus. Trends Ecol. Evol. 2012, 27, 145-150. [CrossRef]

7. Padoa-Schioppa, E.; Baietto, M.; Massa, R.; Bottoni, L. Bird communities as bioindicators: The focal species concept in agricultural landscapes. Ecol. Indic. 2006, 6, 83-93. [CrossRef]

8. Srinivasan, U.; Wilcove, D.S. Interactive impacts of climate change and land-use change on the demography of montane birds. Ecology 2021, 102, e03223. [CrossRef]

9. Sekercioglu, C.H.; Schneider, S.H.; Fay, J.P.; Loarie, S.R. Climate Change, Elevational Range Shifts, and Bird Extinctions. Conserv. Biol. 2007, 22, 140-150. [CrossRef] [PubMed]

10. Smeraldo, S.; Bosso, L.; Fraissinet, M.; Bordignon, L.; Brunelli, M.; Ancillotto, L.; Russo, D. Modelling risks posed by wind turbines and power lines to soaring birds: The black stork (Ciconia nigra) in Italy as a case study. Biodivers. Conserv. 2020, 29, 1959-1976. [CrossRef]

11. Machar, I.; Poprach, K.; Harmacek, J.; Fialova, J. Bird Diversity as a Support Decision Tool for Sustainable Management in Temperate Forested Floodplain Landscapes. Sustainability 2019, 11, 1527. [CrossRef]

12. Sohl, T.L. The Relative Impacts of Climate and Land-Use Change on Conterminous United States Bird Species from 2001 to 2075. PLoS ONE 2014, 9, e112251. [CrossRef] [PubMed]

13. Wauchope, H.; Shaw, J.; Varpe, Ø.; Lappo, E.; Boertmann, D.; Lanctot, R.; Fuller, R.A. Rapid climate-driven loss of breeding habitat for Arctic migratory birds. Glob. Chang. Biol. 2017, 23, 1085-1094. [CrossRef] [PubMed]

14. Titeux, N.; Henle, K.; Mihoub, J.-B.; Regos, A.; Geijzendorffer, I.R.; Cramer, W.; Verburg, P.H.; Brotons, L. Biodiversity scenarios neglect future land-use changes. Glob. Chang. Biol. 2016, 22, 2505-2515. [CrossRef] [PubMed]

15. da Silva, M.X.; Paviolo, A.; Tambosi, L.; Pardini, R. Effectiveness of Protected Areas for biodiversity conservation: Mammal occupancy patterns in the Iguaçu National Park, Brazil. J. Nat. Conserv. 2018, 41, 51-62. [CrossRef]

16. Di Minin, E.; Toivonen, T. Global Protected Area Expansion: Creating More than Paper Parks. Bioscience 2015, 65, 637-638. [CrossRef]

17. Tantipisanuh, N.; Savini, T.; Cutter, P.; Gale, G.A. Biodiversity gap analysis of the protected area system of the Indo-Burma Hotspot and priorities for increasing biodiversity representation. Biol. Conserv. 2016, 195, 203-213. [CrossRef]

18. Hannah, L.; Midgley, G.; Andelman, S.; Araújo, M.; Hughes, G.; Martinez-Meyer, E.; Pearson, R.; Williams, P. Protected area needs in a changing climate. Front. Ecol. Environ. 2007, 5, 131-138. [CrossRef] 
19. Dinerstein, E.; Olson, D.; Joshi, A.; Vynne, C.; Burgess, N.D.; Wikramanayake, E.; Hahn, N.; Palminteri, S.; Hedao, P.; Noss, R.; et al. An Ecoregion-Based Approach to Protecting Half the Terrestrial Realm. Bioscience 2017, 67, 534-545. [CrossRef]

20. Sodhi, N.S.; Smith, K.G. Conservation of tropical birds: Mission possible? J. Ornithol. 2007, 148, 305-309. [CrossRef]

21. Radosavljevic, A.; Anderson, R.P. Making better Maxent models of species distributions: Complexity, overfitting and evaluation. J. Biogeogr. 2014, 41, 629-643. [CrossRef]

22. Hughes, A.; Satasook, C.; Bates, P.; Bumrungsri, S.; Jones, G. The projected effects of climatic and vegetation changes on the distribution and diversity of Southeast Asian bats. Glob. Chang. Biol. 2012, 18, 1854-1865. [CrossRef]

23. Fick, S.E.; Hijmans, R.J. WorldClim 2: New 1-km spatial resolution climate surfaces for global land areas. Int. J. Climatol. 2017, 37, 4302-4315. [CrossRef]

24. Porfirio, L.; Harris, R.; Lefroy, E.; Hugh, S.; Gould, S.; Lee, G.; Bindoff, N.L.; Mackey, B. Improving the use of species distribution models in con-servation planning and management under climate change. PLoS ONE 2014, 9, e113749. [CrossRef]

25. Avalos, V.d.R.; Hernández, J. Projected distribution shifts and protected area coverage of range-restricted Andean birds under climate change. Glob. Ecol. Conserv. 2015, 4, 459-469. [CrossRef]

26. Li, X.; Chen, G.; Liu, X.; Liang, X.; Wang, S.; Chen, Y.; Pei, F.; Xu, X. A New Global Land-Use and Land-Cover Change Product at a 1-km Resolution for 2010 to 2100 Based on Human-Environment Interactions. Ann. Am. Assoc. Geogr. 2017, 107, 1040-1059. [CrossRef]

27. Singh, M.; Cheyne, S.; Ehlers Smith, D. How conspecific primates use their habitats: Surviving in an anthropogenically-disturbed forest in Central Kalimantan, Indonesia. Ecol. Indic. 2018, 87, 167-177. [CrossRef]

28. Pasquale, G.D.; Saracino, A.; Bosso, L.; Russo, D.; Moroni, A.; Bonanomi, G.; Allevato, E. Coastal pine-oak glacial refugia in the Mediterranean basin: A biogeographic approach based on charcoal analysis and spatial modelling. Forests 2020, 11, 673. [CrossRef]

29. Phillips, S.J.; Anderson, R.P.; Dudík, M.; Schapire, R.E.; Blair, M.E. Opening the black box: An open-source release of Maxent. Ecography 2017, 40, 887-893. [CrossRef]

30. Srivastava, V.; Roe, A.D.; Keena, M.A.; Hamelin, R.C.; Griess, V.C. Oh the places they'll go: Improving species distribution modelling for invasive forest pests in an uncertain world. Biol. Invasions 2021, 23, 297-349. [CrossRef]

31. Phillips, S.; Dudík, M. Modeling of species distributions with Maxent: New extensions and a comprehensive evaluation. Ecography 2008, 31, 161-175. [CrossRef]

32. Urbina-Cardona, J.; Loyola, R. Applying Niche-Based Models to Predict Endangered-Hylid Potential Distributions: Are Neotropical Protected Areas Effective Enough? Trop. Conserv. Sci. 2008, 1, 417-445. [CrossRef]

33. Cameron, A.; Trivedi, P.K. Microeconometrics: Methods and Applications; Cambridge University Press: Cambridge, NY, USA, 2005.

34. Allouche, O.; Tsoar, A.; Kadmon, R. Assessing the accuracy of species distribution models: Prevalence, kappa and the true skill statistic (TSS). J. Appl. Ecol. 2006, 43, 1223-1232. [CrossRef]

35. Peterson, A.; Papeş, M.; Soberón, J. Rethinking receiver operating characteristic analysis applications in ecological niche modeling. Ecol Model. 2008, 213, 63-72. [CrossRef]

36. Wisz, M.; Hijmans, R.; Li, J.; Peterson, A.; Graham, C.; Guisan, A.; NCEAS Predicting Species Distributions Working Group. Effects of sample size on the performance of species distribution models. Divers. Distrib. 2008, 14, 763-773. [CrossRef]

37. Coxen, C.L.; Frey, J.K.; Carleton, S.A.; Collins, D.P. Species distribution models for a migratory bird based on citizen science and satellite tracking data. Glob. Ecol. Conserv. 2017, 11, 298-311. [CrossRef]

38. Nazeri, M.; Jusoff, K.; Madani, N.; Mahmud, A.; Bahman, A.; Kumar, L. Predictive modeling and mapping of Malayan Sun Bear (Helarctos malayanus) distribution using maximum entropy. PLoS ONE 2012, 7, e48104. [CrossRef]

39. Escalante, T.; Rodríguez-Tapia, G.; Linaje, M.; Illoldi-Rangel, P.; González-López, R. Identification of areas of endemism from species distribution models: Threshold selection and Nearctic mammals. TIP 2013, 16, 5-17. [CrossRef]

40. Freeman, B.; Sunnarborg, J.; Peterson, A.T. Effects of climate change on the distributional potential of three range-restricted West African bird species. Condor 2019, 121. [CrossRef]

41. R Foundation for Statistical Computing VA. R Foundation for Statistical Computing RCT. R: A Language and Environment for Statistical Computing. Austria: R Foundation for Statistical Computing, Vienna, Austria. 2020. Available online: https: / /www.R-project.org/ (accessed on 1 March 2020).

42. Singh, M. Evaluating the impact of future climate and forest cover change on the ability of Southeast (SE) Asia's protected areas to provide coverage to the habitats of threatened avian species. Ecol. Indic. 2020, 114, 106307. [CrossRef]

43. Brus, J.; Pechanec, V.; Machar, I. Depiction of uncertainty in the visually interpreted land cover data. Ecol. Inform. 2018, 47, 10-13. [CrossRef]

44. Struebig, M.J.; Fischer, M.; Gaveau, D.L.; Meijaard, E.; Wich, S.A.; Gonner, C.; Sykes, R.; Wilting, A.; Kramer-Schadt, S. Anticipated climate and land-cover changes reveal refuge areas for Borneo's orang-utans. Glob. Chang. Biol. 2015, 21, 2891-2904. [CrossRef]

45. Alamgir, M.; Campbell, M.J.; Sloan, S.; Suhardiman, A.; Supriatna, J.; Laurance, W.F. High-risk infrastructure projects pose imminent threats to forests in Indonesian Borneo. Sci. Rep. 2019, 9, 1-10. [CrossRef]

46. Mantyka-Pringle, C.; Visconti, P.; Di Marco, M.; Martin, T.; Rondinini, C.; Rhodes, J. Climate change modifies risk of global bio-diversity loss due to land-cover change. Biol. Conserv. 2015, 187, 103-111. [CrossRef]

47. Scriven, S.; Hodgson, J.; McClean, C.; Hill, J. Protected areas in Borneo may fail to conserve tropical forest biodiversity under climate change. Biol. Conserv. 2015, 184, 414-423. [CrossRef] 
48. Freeman, B.; Class Freeman, A. Rapid upslope shifts in New Guinean birds illustrate strong distributional responses of tropical montane species to global warming. Proc. Natl. Acad. Sci. USA 2014, 111, 4490-4494. [CrossRef]

49. Freeman, B.; Scholer, M.; Ruiz-Gutierrez, V.; Fitzpatrick, J. Climate change causes upslope shifts and mountaintop extirpa-tions in a tropical bird community. Proc. Natl. Acad. Sci. USA 2018, 115, 11982-11987. [CrossRef]

50. La Sorte, F.; Jetz, W. Projected range contractions of montane biodiversity under global warming. Proc. Biol. Sci. 2010, 277, 3401-3410. [CrossRef] [PubMed]

51. Colwell, R.; Brehm, G.; Cardelús, C.; Gilman, A.; Longino, J. Global warming, elevational range shifts, and lowland biotic attrition in the wet tropics. Science 2008, 322, 258-261. [CrossRef] [PubMed]

52. Ramirez-Villegas, J.; Cuesta, F.; Devenish, C.; Peralvo, M.; Jarvis, A.; Arnillas, C. Using species distributions models for designing conservation strategies of Tropical Andean biodiversity under climate change. J. Nat. Conserv. 2014, 22, 391-404. [CrossRef]

53. Jose, V.S.; Nameer, P. The expanding distribution of the Indian Peafowl (Pavo cristatus) as an indicator of changing climate in Kerala, southern India: A modelling study using Maxent. Ecol. Indic. 2020, 110, 105930. [CrossRef]

54. Velásquez-Tibatá, J.; Salaman, P.; Graham, C. Effects of climate change on species distribution, community structure, and conservation of birds in protected areas in Colombia. Reg. Environ. Chang. 2013, 13, 235-248. [CrossRef]

55. Rodrigues, A.; Akçakaya, H.; Andelman, S.; Bakarr, M.; Boitani, L.; Brooks, T.; Chanson, J.S.; Fishpool, L.D.C.; Da Fonseca, G.A.B.; Gaston, K.J.; et al. Global Gap Analysis: Priority Regions for Expanding the Global Protected-Area Network. Bioscience 2004, 54, 1092. [CrossRef]

56. Cazalis, V.; Princé, K.; Mihoub, J.B.; Kelly, J.; Butchart, S.; Rodrigues, A. Effectiveness of protected areas in conserving tropical forest birds. Nat. Commun. 2020, 11, 4461. [CrossRef] [PubMed]

57. Bosso, L.; Smeraldo, S.; Rapuzzi, P.; Sama, G.; Garonna, A.P.; Russo, D. Nature protection areas of Europe are insufficient to preserve the threatened beetle Rosalia alpina (Coleoptera: Cerambycidae): Evidence from species distribution models and conservation gap analysis. Ecol. Entomol. 2018, 43, 192-203. [CrossRef]

58. Hickcox, R.P.; Jara, M.; Deacon, L.A.K.; Harvey, L.P.; Pincheira-Donoso, D. Global terrestrial distribution of penguins (Spheniscidae) and their conservation by protected areas. Biodivers. Conserv. 2019, 28, 2861-2876. [CrossRef]

59. De Klerk, H.; Fjeldså, J.; Blyth, S.; Burgess, N. Gaps in the protected area network for threatened Afrotropical birds. Biol. Conserv. 2004, 117, 529-537. [CrossRef]

60. Gaüzère, P.; Jiguet, F.; Devictor, V. Can protected areas mitigate the impacts of climate change on bird's species and communities? Divers. Distrib. 2016, 22, 625-637. [CrossRef]

61. Garden, J.; O'Donnell, T.; Catterall, C. Changing habitat areas and static reserves: Challenges to species protection under climate change. Landsc. Ecol. 2015, 30, 1959-1973. [CrossRef]

62. Wan, J.; Wang, C.; Han, S.; Yu, J. Planning the priority protected areas of endangered orchid species in northeastern China. Biodivers. Conserv. 2014, 23, 1395-1409. [CrossRef]

63. Newbold, T. Future effects of climate and land-use change on terrestrial vertebrate community diversity under different scenarios. Proc. Biol. Sci. 2018, 285, 1881. [CrossRef]

64. Sharma, S.; Baral, H.; Laumonier, Y.; Okarda, B.; Komarudin, H.; Purnomo, H.; Pacheco, P. Ecosystem services under future oil palm expansion scenarios in West Kalimantan, Indonesia. Ecosyst. Serv. 2019, 39, 100978. [CrossRef]

65. Savolainen, V.; Clottey, V.A.; Doubi, B.T.S.; Konan, J.L.; Quain, M.; Bezeng, B.S.; Logah, V.; Wireko-Kena, A.; Osekre, E.A.; Atuah, L.; et al. Systems thinking creates opportunities for a circular economy and sustainable palm agriculture in Africa. Curr. Res. Environ. Sustain. 2020, 1, 31-34. [CrossRef] 